\title{
Experimental Investigation on Concrete Filled Steel Tube Columns under Concentric and Eccentric Loading
}

\author{
Panya Klongaksornkul, Kitjapat Phuvoravan*
}

Department of Civil Engineering, Kasetsart University, Bangkok, Thailand

Received August 27, 2021; Revised October 26, 2021; Accepted November 11, 2021

\section{Cite This Paper in the following Citation Styles}

(a): [1] Panya Klongaksornkul, Kitjapat Phuvoravan, "Experimental Investigation on Concrete Filled Steel Tube Columns under Concentric and Eccentric Loading," Civil Engineering and Architecture, Vol. 9, No. 7, pp. 2397 - 2415, 2021. DOI: 10.13189/cea.2021.090726.

(b): Panya Klongaksornkul, Kitjapat Phuvoravan (2021). Experimental Investigation on Concrete Filled Steel Tube Columns under Concentric and Eccentric Loading. Civil Engineering and Architecture, 9(7), 2397 - 2415. DOI: 10.13189/cea.2021.090726.

Copyright $\subseteq 2021$ by authors, all rights reserved. Authors agree that this article remains permanently open access under the terms of the Creative Commons Attribution License 4.0 International License

\begin{abstract}
Modern construction projects such as skyscrapers, bridge with a large span, residential structures, towers for transmission, warehouses and other industrial structures have all incorporated concrete-filled steel tube (CFST) columns. Fire resistance, excellent ductility and high bearing capacity are all the advantages of CFST columns. Among the different shapes of CFST columns, uses of rectangular and square CFST columns are becoming more favored in modern construction projects for their simple beam-to-column connections design. This study tested 10 concentrically loaded CFST columns and 8 eccentrically loaded CFST columns. One of the most effective techniques to delay local buckling and enhance the ultimate strength of the CFST columns is to use longitudinal inner stiffeners on these steel tubes. Cold-formed steel tube sections are vulnerable due to local buckling; however, a concrete core is able to restrict such early local buckling in the cold-formed steel tube. The test specimens consisted of unstiffened sections and longitudinal inner-stiffened sections. In total, the experimental program tested 18 CFST stub columns with both compact and slender sections, without longitudinal stiffener, with 2 longitudinal inner stiffeners and with 4 longitudinal stiffeners. The test strengths have been as compared with predictions based on the existing design code AISC 360-16 for calculating the ultimate capacities of the CFST stub columns subjected to both concentric and eccentric loading. The focus was mainly on the effect of vertical stiffener square concrete-filled steel tubes on the overall concentric and eccentric compression capacity. The
\end{abstract}

results identified that the longitudinal inner stiffeners had a significant impact on the ultimate strength, deformability and mode of failure in the CFST stub columns. To prevent local buckling of such steel tube, a longitudinal inner stiffener could be applied. In addition, the compression capacity was increased by $12-13.5 \%$.

Keywords Concrete-Filled Steel Tube, Longitudinal Inner Stiffened Sections, Ultimate Strength

\section{Introduction}

In the past decade, especially in Asia, concrete-filled steel tubes (CFST) were becoming more popular in skyscrapers, bridges, other industrial structures and pile constructions because CFST has advantages of high ductility, high energy absorption capacity, good strength and stiffness and saves cost in construction. With the confinement effect, the capacity of a square/rectangular CFST is clearly inferior to that of circular concrete-filled steel tube. The rectangular/ square shapes exhibit reduction on both the lateral confining pressure when compared to circular CFST and with the enhancement of high strength steel; this becomes very noticeable in cold-formed steel tubes as local buckling is delayed in failure mode. Due to local buckling, cold-formed steel tube is vulnerable; however, cold-formed steel tube can be prevented from buckling locally by using concrete. The 
cold-formed steel tube reduces excessive concrete spalling when compared to a traditional steel frame, while CFST columns increase the rigidity strength of frame. Additionally, CFST columns have the advantage of eliminating the need for formwork during construction, thereby reducing construction cost. Square and rectangular cross section columns are used in commercial buildings due to their ease of assembly in beam-column joints, higher bending stiffness and architectural aesthetics. Welding built-up square steel tube assembled from 4L-shape cold rolled steel plates, welding longitudinal stiffener on each steel tube's inner face, welding cold-formed steel channels, and welding shear studs on each tube face are all examples of longitudinal stiffener procedures used in CFST columns. Ge and Usami [1] developed longitudinal inner stiffeners to improve the performances of square/rectangular CFST stub columns. In their experiments, local failure mode of the steel tube was hampered by longitudinal stiffeners. Bridge [2] investigated the behavior of square section of thin-wall steel under a concentric load. The specimen had a B/t ratio between 37.3 and 130.7 and the results indicated that unbonded concrete-infilled square steel tube provided restraint to local buckling effect and could increase the strength in excess of that for the bare steel tubes. Han [3] studied experimentally 24 tests on rectangular CFST columns to observe the influence of the constraining factor $(\xi)$ and width ratio $(\beta)$ on the performances of a rectangular hollow section filled with concrete. Subjected to concentric compression load, Tao's report [4] showed the effect of CFST columns with external or internal welded stiffeners in a longitudinal direction. CFST stub columns with longitudinal stiffeners have a higher capacity than non-stiffener CFST stub columns in a longitudinal direction remaining to the lateral constraint on the concrete core.

In concentric compression, Yang [5] investigated 2 non-stiffened counterparts and 8 stiffened square CFST stub columns with high slenderness ratio of enclosing steel to study the stiffeners affected the tube's local buckling. Lee, et al. [6], Du, et al. [7], and Yuan [8] performed current experimental programs on rectangular and square beams composed of high-strength steel under an eccentric load. The current paper presents experimental data about the behavior of a thin-walled tabular section filled with concrete with longitudinal stiffening under axial compressive loading and eccentric compressive loading. Ten CFST stub column samples were used for concentric load testing; moreover, eight CFST stub columns were investigated subjected to the eccentric axial load. The specimens consisted of 10 stub columns: 4 columns with a longitudinal stiffener on each internal face of the cold-formed steel tube, 3 columns with stiffeners in a longitudinal direction on the two other sides for internal faces of the cold-formed steel tube and 3 columns with non-longitudinal stiffener of cold-formed carbon steel tubes. In total, 10 typical concrete-filled steel tubes using cold-formed carbon steel and high tensile cold-rolled steel, with a tabular thickness of $1.5 \mathrm{~mm}$ and $3.2 \mathrm{~mm}$ were built and tested under concentric compression load as depicted in Figure 1. To save cost on construction, the steel wall thickness should be decreased as the yield strength increases. The CFST stub columns for concentric loading tests are described in Table 1 . Similarly, the specimens utilized in the eccentric loading test to establish the load-carrying capability of the CFST stub columns are described in Figure 2 and Table 2. Cold-formed steel channels and angles are lightweight structural steel members, designed according with the AS/NZS 4600. Cold-formed steel channels and angles in base metal with various thicknesses $(1.0,1.2,1.5,2.4$, and $3.0 \mathrm{~mm})$ are available with or without a zinc coat. The cold-formed tubular steel square columns filled with concrete had been assembled for the test by welding 4 pieces of lipped-angled cold-formed steel and welding two pieces of lipped channels (2C shape) cold-formed steel as illustrated in Figure 3. The rectangular or square tube was filled with nominal concrete. The buckling modes of CFT with 2 stiffeners and 4 stiffeners are shown in Figure 4. 


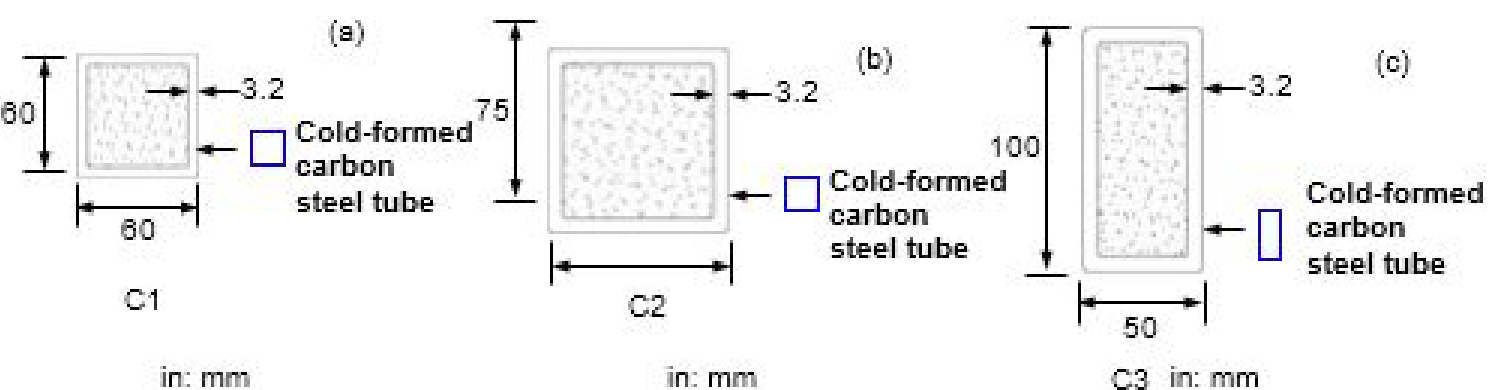

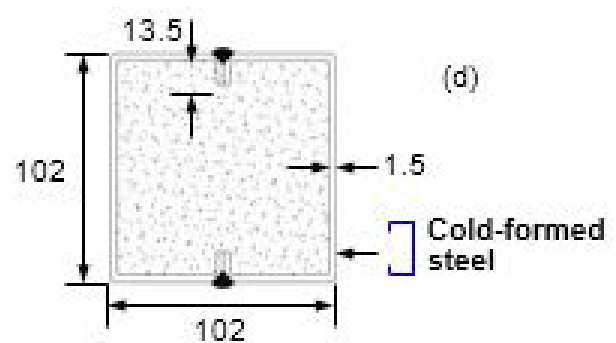

$\mathrm{C4}$ in: $\mathrm{mm}$
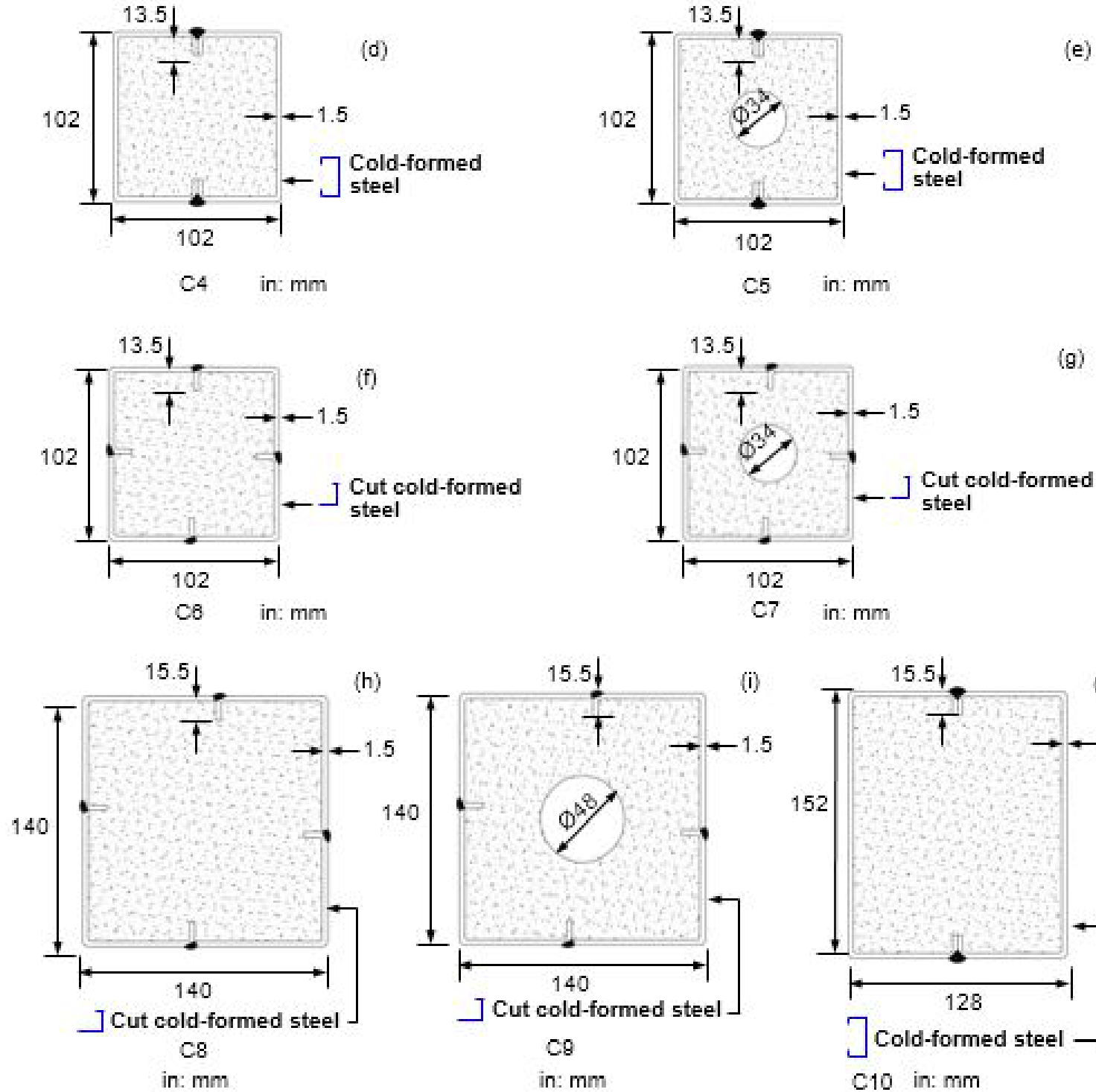

(e)

C5 in: $\mathrm{mm}$

)

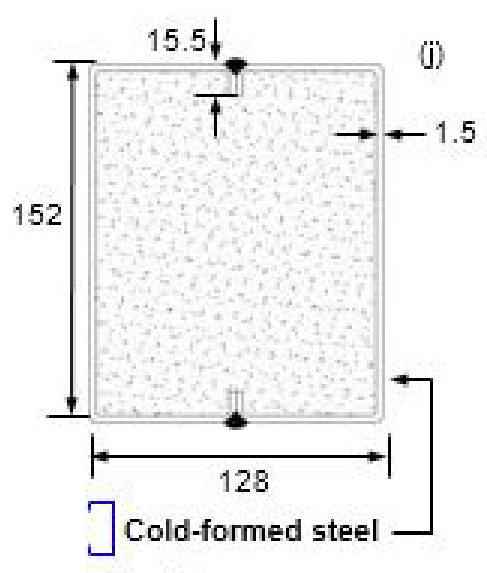

$\mathrm{C} 10$ in: $\mathrm{mm}$

Figure 1. Dimensions of CFST stub columns with cold-formed carbon steel and high-tensile cold-rolled steel subjected to axial compressive loading. 
Table 1. Summary details of test CFST specimens under concentric loading

\begin{tabular}{|c|c|c|c|c|c|c|c|c|c|c|c|}
\hline Series & $\begin{array}{l}\text { Specimen } \\
\text { label }\end{array}$ & $\begin{array}{l}\text { Width } \\
\text { B (mm) }\end{array}$ & $\begin{array}{c}\text { Height } \\
\text { H (mm) }\end{array}$ & $\begin{array}{l}\text { Thickness } \\
\text { T (mm) }\end{array}$ & $\begin{array}{c}\mathbf{h}_{\mathrm{s}} \\
(\mathrm{mm})\end{array}$ & $\begin{array}{c}\text { Hole Diameter, } \\
\phi \\
(\mathrm{mm}) \\
\end{array}$ & $\begin{array}{c}\mathbf{f}_{\mathrm{c}} \\
\text { (MPa) }\end{array}$ & $\begin{array}{c}\mathbf{f}_{\mathrm{y}} \\
(\mathbf{M P a})\end{array}$ & $\begin{array}{c}A_{s} \\
\left(\mathrm{~mm}^{2}\right)\end{array}$ & $\begin{array}{c}A_{c} \\
\left(\mathbf{m m}^{2}\right)\end{array}$ & $\begin{array}{r}\mathbf{N}_{\mathrm{ue}} \\
(\mathbf{k N})\end{array}$ \\
\hline \multirow{3}{*}{1} & C1 & 60 & 60 & 3.2 & - & - & 31.8 & 370 & 700.7 & 2,899 & 375 \\
\hline & C2 & 75 & 75 & 3.2 & - & - & 31.8 & 370 & 892.7 & 4,732 & 450 \\
\hline & C3 & 50 & 100 & 3.2 & - & - & 31.8 & 370 & 892.7 & 4,107 & 405 \\
\hline \multirow{4}{*}{2} & $\mathrm{C} 4$ & 102 & 102 & 1.5 & 13.5 & - & 31.8 & 479.2 & 646 & 9,758 & 507 \\
\hline & C5 & 102 & 102 & 1.5 & 13.5 & 34 & 31.8 & 479.2 & 646 & 8,850 & 469 \\
\hline & C6 & 102 & 102 & 1.5 & 13.5 & - & 31.8 & 479.2 & 646 & 9,758 & 576 \\
\hline & C7 & 102 & 102 & 1.5 & 13.5 & 34 & 31.8 & 479.2 & 646 & 8,850 & 542 \\
\hline \multirow{3}{*}{3} & C8 & 140 & 140 & 1.5 & 15.5 & - & 31.8 & 479.2 & 886 & 18,714 & 937 \\
\hline & C9 & 140 & 140 & 1.5 & 15.5 & 48 & 31.8 & 479.2 & 886 & 16,904 & 880 \\
\hline & C10 & 128 & 152 & 1.5 & 15.5 & - & 31.8 & 479.2 & 886 & 18,570 & 994 \\
\hline
\end{tabular}

Table 2. Summary details of test CFST specimens under eccentric loading

\begin{tabular}{|c|c|c|c|c|c|c|c|c|c|c|c|c|c|}
\hline Series & $\begin{array}{c}\text { Specimen } \\
\text { label }\end{array}$ & $\begin{array}{l}\text { Width } \\
\text { B (mm) }\end{array}$ & $\begin{array}{l}\text { Height } \\
\text { H(mm) }\end{array}$ & $\begin{array}{c}\text { Thickness } \\
\text { t(mm) }\end{array}$ & $\begin{array}{c}\mathbf{h}_{\mathrm{s}} \\
(\mathbf{m m})\end{array}$ & $\begin{array}{c}\text { Hole } \\
\text { Diameter, } \\
\phi \\
(\mathbf{m m})\end{array}$ & $\begin{array}{c}\mathbf{f}_{\mathrm{c}}{ }^{\prime} \\
(\mathbf{M P a})\end{array}$ & $\begin{array}{c}\mathbf{f}_{\mathbf{y}} \\
(\mathbf{M P a})\end{array}$ & $\begin{array}{c}A_{s} \\
\left(\mathbf{m m}^{2}\right)\end{array}$ & $\begin{array}{c}A_{c} \\
\left(\mathbf{m m}^{2}\right)\end{array}$ & $\underset{(\mathrm{mm})}{\mathrm{e}}$ & $\begin{array}{l}N_{\mathrm{ue}} \\
(\mathrm{kN})\end{array}$ & $\begin{array}{c}\text { M } \\
(\mathbf{k N}-\mathbf{m})\end{array}$ \\
\hline \multirow{2}{*}{1} & C11 & 60 & 60 & 3.2 & - & - & 31.8 & 370 & 700.7 & 2,899 & 15 & 221 & 3.32 \\
\hline & C12 & 75 & 75 & 3.2 & - & - & 31.8 & 370 & 892.7 & 4,732 & 25 & 244 & 6.10 \\
\hline \multirow{4}{*}{2} & $\mathrm{C} 13$ & 102 & 102 & 1.5 & 13.5 & - & 31.8 & 479.2 & 646 & 9,758 & 25 & 349 & 8.73 \\
\hline & C14 & 102 & 102 & 1.5 & 13.5 & 34 & 31.8 & 479.2 & 646 & 8,850 & 25 & 347 & 8.68 \\
\hline & C15 & 102 & 102 & 1.5 & 13.5 & - & 31.8 & 479.2 & 646 & 9,758 & 25 & 338 & 8.45 \\
\hline & C16 & 102 & 102 & 1.5 & 13.5 & 34 & 31.8 & 479.2 & 646 & 8,850 & 25 & 369 & 9.25 \\
\hline \multirow{2}{*}{3} & C17 & 140 & 140 & 1.5 & 15.5 & - & 31.8 & 479.2 & 886 & 18,714 & 25 & 700 & 17.5 \\
\hline & C18 & 140 & 140 & 1.5 & 15.5 & 48 & 31.8 & 479.2 & 886 & 16,904 & 25 & 683 & 17.0 \\
\hline
\end{tabular}


(a)

(b)

60
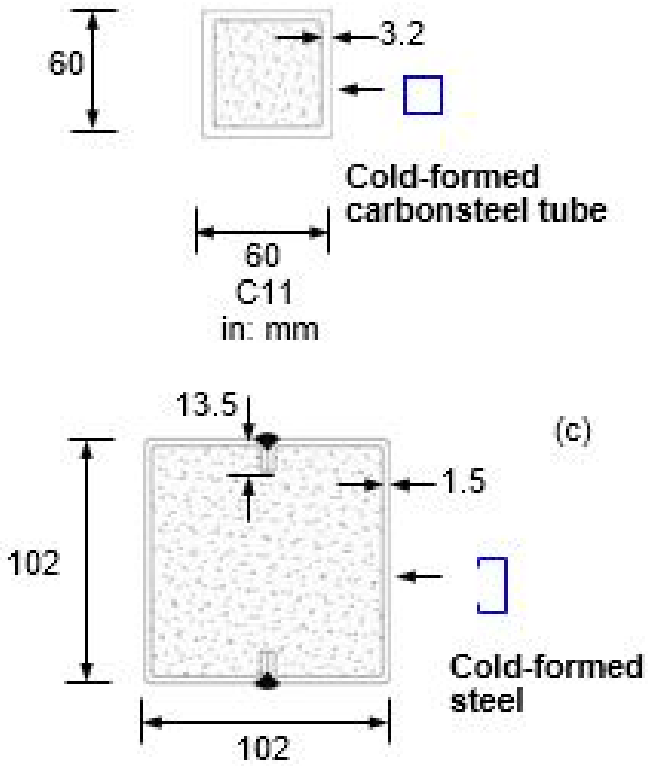

C13

in: $\mathrm{mm}$

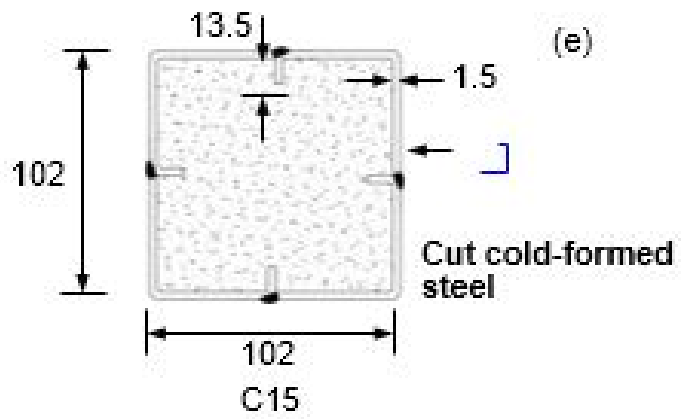

in: $\mathrm{mm}$

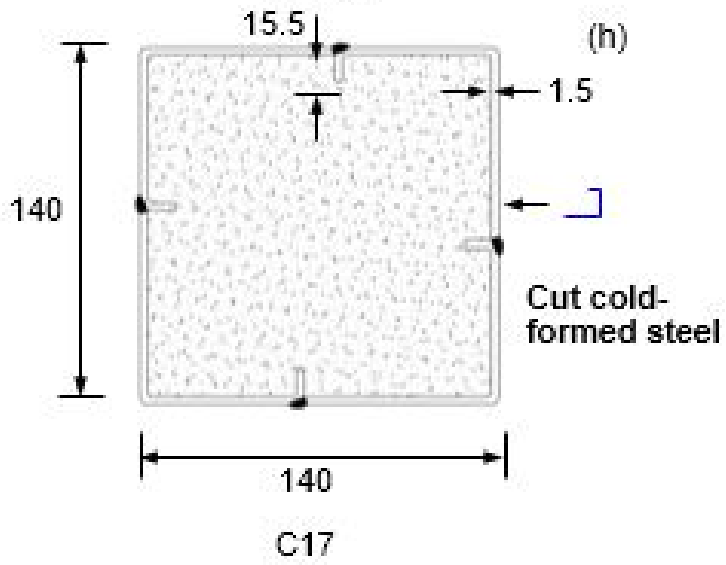

in: $\mathrm{mm}$
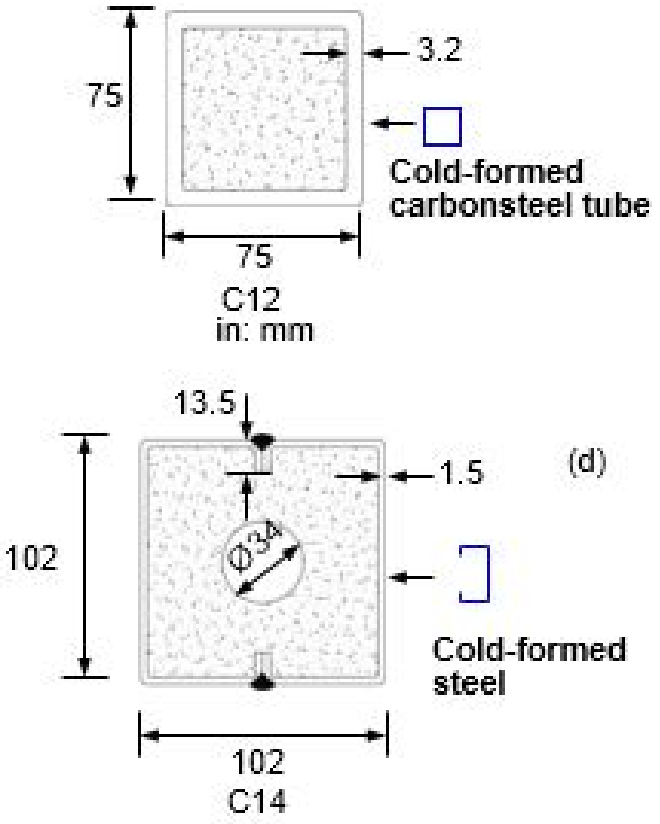

in: $\mathrm{mm}$

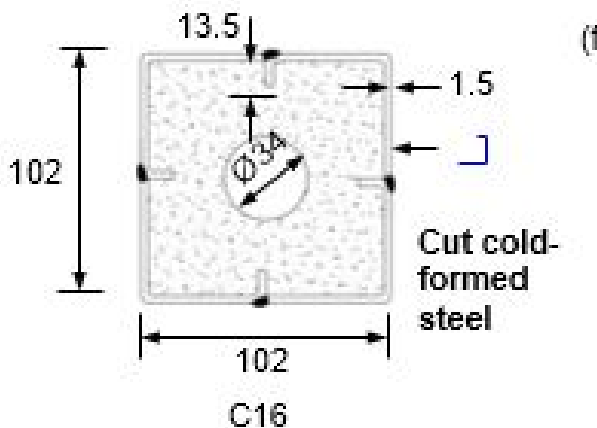

in: $\mathrm{mm}$

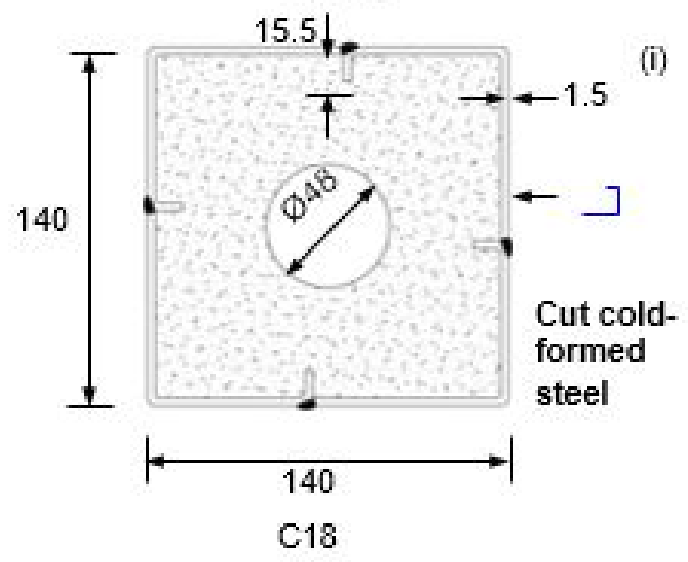

in: $\mathrm{mm}$

Figure 2. Dimensions of CFST stub columns with cold-formed carbon steel and high-tensile-cold rolled steel subjected to eccentric compressive loading 


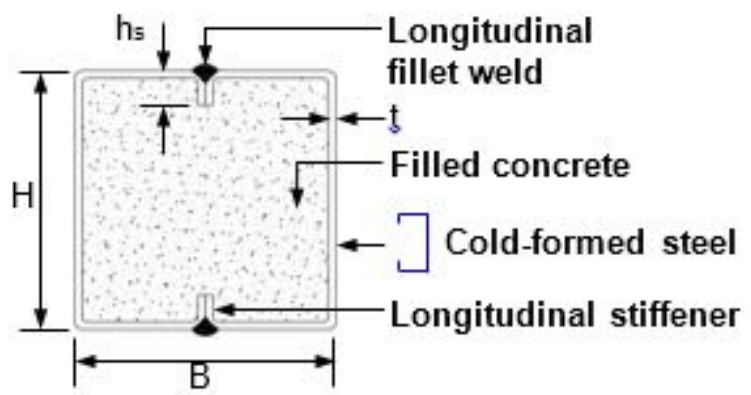

(a) two stiffeners

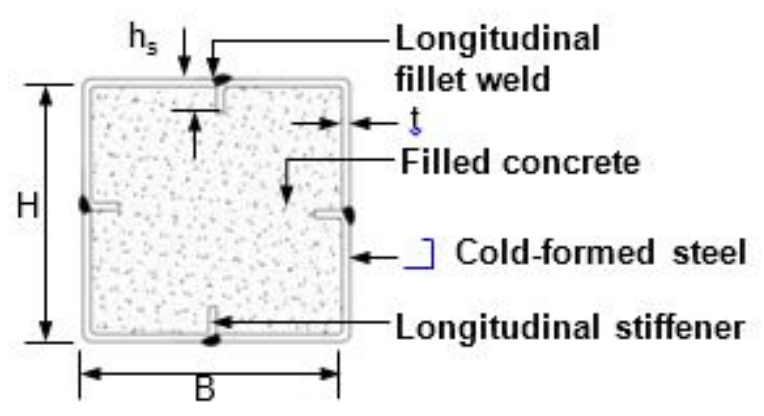

(b) four stiffeners

Figure 3. Cold-formed steels used in CFST stub columns
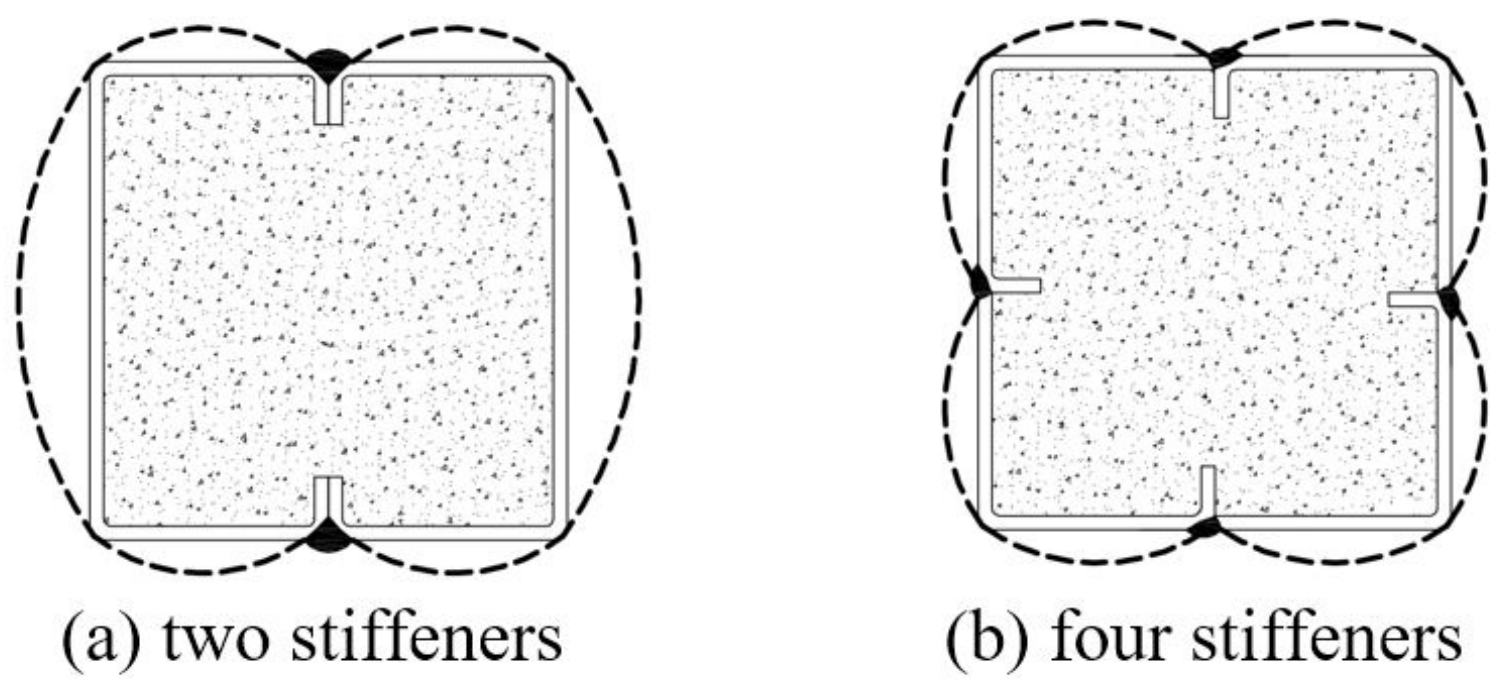

Figure 4. Possible local buckling of square CFST stub columns

\section{Experimental Program}

In the experimental work, 18 specimens including longitudinal inner stiffened sections and without longitudinal inner stiffened sections were used for concentric and eccentric testing. The study is mainly divided into evaluate the ultimate strength capacity of the specimens and examine the impact of the longitudinal inner stiffener details on the strength of the CFST columns made with high tensile cold-rolled steel tube. In this research, welded, built-up square steel tubes have been fabricated by welding 2 channel-lipped steel sections and 4 angle-lipped steel sections together. The residual stress of the weld in this experiment should not affect the ultimate resistances of all the CFST column with the high-tensile cold rolled steel tube.

\subsection{Material Properties}

\subsubsection{Steel Box}

The stub column specimens using cold-formed carbon steel and high-tensile cold-rolled steel, with tabular thicknesses of $1.5 \mathrm{~mm}$ and $3.2 \mathrm{~mm}$, were produced and tested under axial compressive loads and eccentric loads. This study was mainly interested in the concrete-infilled square hollow section columns; concrete-infilled rectangular hollow section columns have been additionally examined. The stub column length was 500 $\mathrm{mm}$. Cold-formed carbon steel and high-tensile cold-rolled steel had yield stresses of $370 \mathrm{MPa}$ and 479.2 MPa, respectively.

\subsubsection{Concrete}

The test specimens were made from ready-mix design of strength concrete. For each mix design, three standard control cylinders specimens $(150 \times 300)$ were cast from batch of concrete mixture and tested to failure to estimate the average compressive strength. Three concrete cylinders were tested 28 days after concrete casting. At 28 days, the average specified concrete compressive strength are provided to have a compressive cylinder strength ( $\left.\mathrm{fc}^{\prime}\right)$ of $31.8 \mathrm{MPa}$. 


\subsection{Specimen Preparation}

The specimens consisted of 2 rectangular and 8 square CFST stub columns. All steel tubes had been made from cold-formed carbon steel JIS G3466 $\left(\mathrm{f}_{\mathrm{y}}=370 \mathrm{MPa}, \mathrm{f}_{\mathrm{u}}=\right.$ $420 \mathrm{MPa}$ ) and high-tensile cold-rolled steel G450, AS1365 $\left(\mathrm{f}_{\mathrm{y}}=479.2 \mathrm{MPa}, \mathrm{f}_{\mathrm{u}}=490 \mathrm{MPa}\right)$. The height of all stub columns was $500 \mathrm{~mm}$. The fundamental geometrical parameters of the specimens, section sizes, areas of the steel tabular $\left(A_{s}\right)$ and areas of the concrete $\left(A_{c}\right)$ are summarized in Table 1 . The stiffeners had lengths $\left(\mathrm{h}_{\mathrm{s}}\right)$ of $13.5 \mathrm{~mm}$ and $15.5 \mathrm{~mm}$, respectively. The width $\mathrm{B}$ and depth $\mathrm{H}$ of all specimens are summarized in Table1. The specimens had been divided into 3 series (Series 1, Series 2 and Series 3). The first series consisted of 2 square CFST columns (C1, C2) and 1 rectangular CFST (C3) with tubular thickness $3.2 \mathrm{~mm}$ and a nominal yield strength $370 \mathrm{MPa}$. The second series consisted of 4 square CFST columns (C4, C5, C6, C7) with tubular thickness $1.5 \mathrm{~mm}$ and a high tensile yield strength of 479.2 MPa. The third series consisted of 2 square CFST columns (C8 and C9) and 1 rectangular CFST (C10) with tubular thickness $1.5 \mathrm{~mm}$ and a nominal yield strength of 479.2 $\mathrm{MPa}$. The specimens denoted as C11 to C18 were the same as those of C1 to C2, and C4 - C9, respectively. The details of specimens are presented in Table 1 and Table 2.

During curing, the concrete-filled steel tube experienced vertical shrinkage at the top. The vertical gap was injected with a non-shrink grout, as well as the concrete cover was poured into the top of steel tube columns. Using a diamond grinding machine, the top covers of the specimens were polished to smoothen and flatten their surface.

The 8 specimens, consisting of 2 non-longitudinal stiffener, cold-formed carbon steel tubes and 6 specimens with longitudinal inner stiffener of high-tensile cold-rolled steel were prepared for the eccentric loading test as shown in Figure 2.

\subsection{Test Set-Up}

Under stroke control in a $1,000 \mathrm{kN}$ capacity testing machine, the 18 specimens were evaluated for varied eccentricity conditions of 0,15 , and $25 \mathrm{~mm}$ (Figure 5). Before the test, each column was centered on the machine for testing. The vertical displacement was recorded using two Linear Variable Displacement Transducers (LVDTs). In addition, a group of 3 LVDTs had been used at the corners and center of the steel tube to measure horizontal displacement of the deflected column. Strain gauges had been placed on the 4 sides of the CFST column. Using a longitudinal strain gauge, the axial strain in the tube's midsection was measured. 

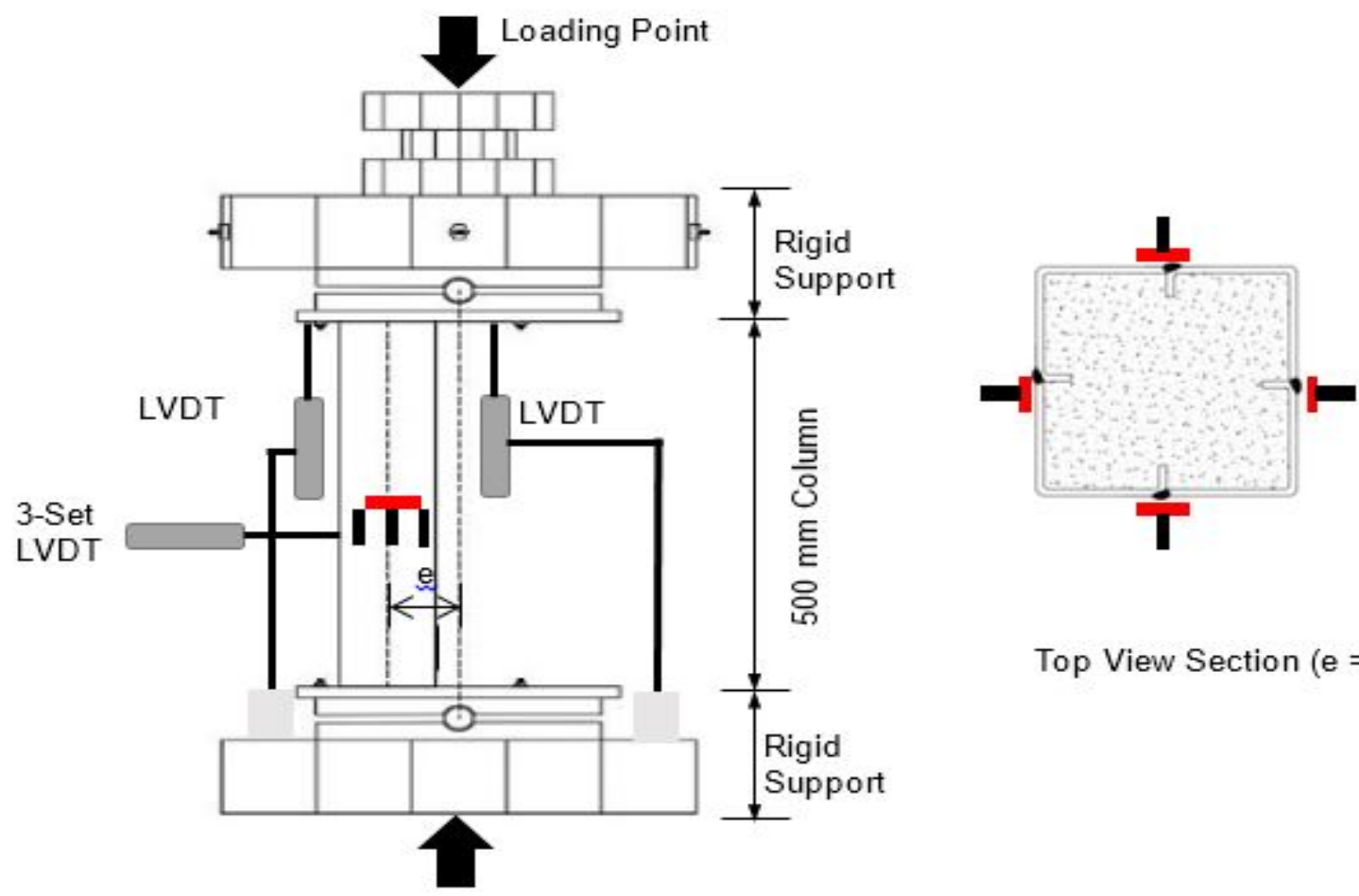

Top View Section $(\mathrm{e}=0 \mathrm{~mm}$.)

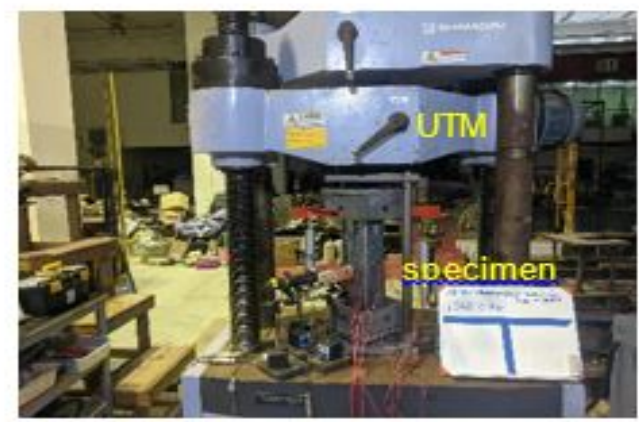

Actual Test Set Up

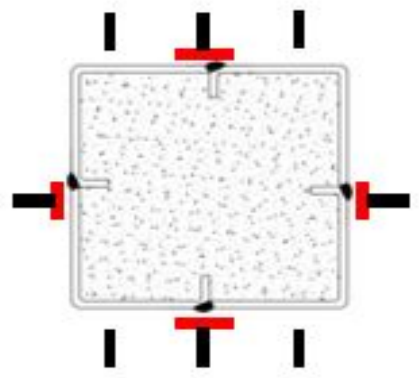

Top View Section $(e=15,25 \mathrm{~mm}$.)

Figure 5. Test set up of CFST stub columns subjected to eccentric loading

Each transverse strain gauge was installed at the mid-height of each column to measure hoop strain. Using a $1000 \mathrm{kN}$ loading machine, each sample was compressed for the control of the displacement load with a speed of $0.2 \mathrm{~mm} / \mathrm{min}$. When the load capacity of the columns dropped to $85 \%$ of their ultimate load capacity, the tests were terminated. An automatic data logger had been used to record all of the data.

\section{Results and Discussion}

\subsection{Failure Modes of CFST}

\subsubsection{Concentric Loading ( $\mathrm{e}=0$ )}

In total, 10 CFST stub columns had been examined to fail under compressive loading. The failure modes in the CFST stub columns were local buckling of steel tube, yielding of steel section, or concrete crushing. Figure 6 illustrates the failure mode of specimens when the compressive loading decreased to $85 \%$ of the peak axial compression load-carrying capacity. In the specimens, local buckling started before ultimate load capacity. The main failure loads were local buckling of the top of the CFST stub column (C4, C9, C10) or bottom CFST stub column (C3, C5, C6, C7, C8) and global buckling (C1 and $\mathrm{C} 2)$. The CFST stub columns showed 2 different failure modes. The CFST stub column with a $3.2 \mathrm{~mm}$ thick steel tube (C1 and C2) exhibited vertical deformation during loading where the vertical deformation slowly developed with the increment of loads, and the CFST stub columns were classified as compact sections, with local buckling occurring originally in one of the CFST stub columns just prior to the peak load was developed and other deformations due to buckling occurred in the CFST stub column after the maximum load. The CFST stub columns with thickness $1.5 \mathrm{~mm}$ (C4-C10) showed the same 
vertical displacement as the CFST stub columns C1 and C2 in the first stage of loading, however while the load exceeded the ultimate load, outward bulges in the steel tube were observed. The increment in vertical deformation began very rapidly after initiation of the first local buckling failure in the steel tube. For the CFST stub columns C6 and C7, local steel tube buckling failure arouse upon reaching the peak load, which happened much later than for the CFST stub columns C4 and C5. This was attributed to the fact that the buckling mode shape of the 4 longitudinal stiffener steel tubes could change from single curvature to double curvature, as shown in Figure 4 because the concrete core was able to delay and prevent local buckling of the longitudinal inner stiffener. The rectangle CFST stub column failed in similar behavior as that of the square CFST stub column. Local buckling on the longer side of the cross section occurred prior to that of the shorter side. The ultimate strengths of CFST columns are provided in Table 1.
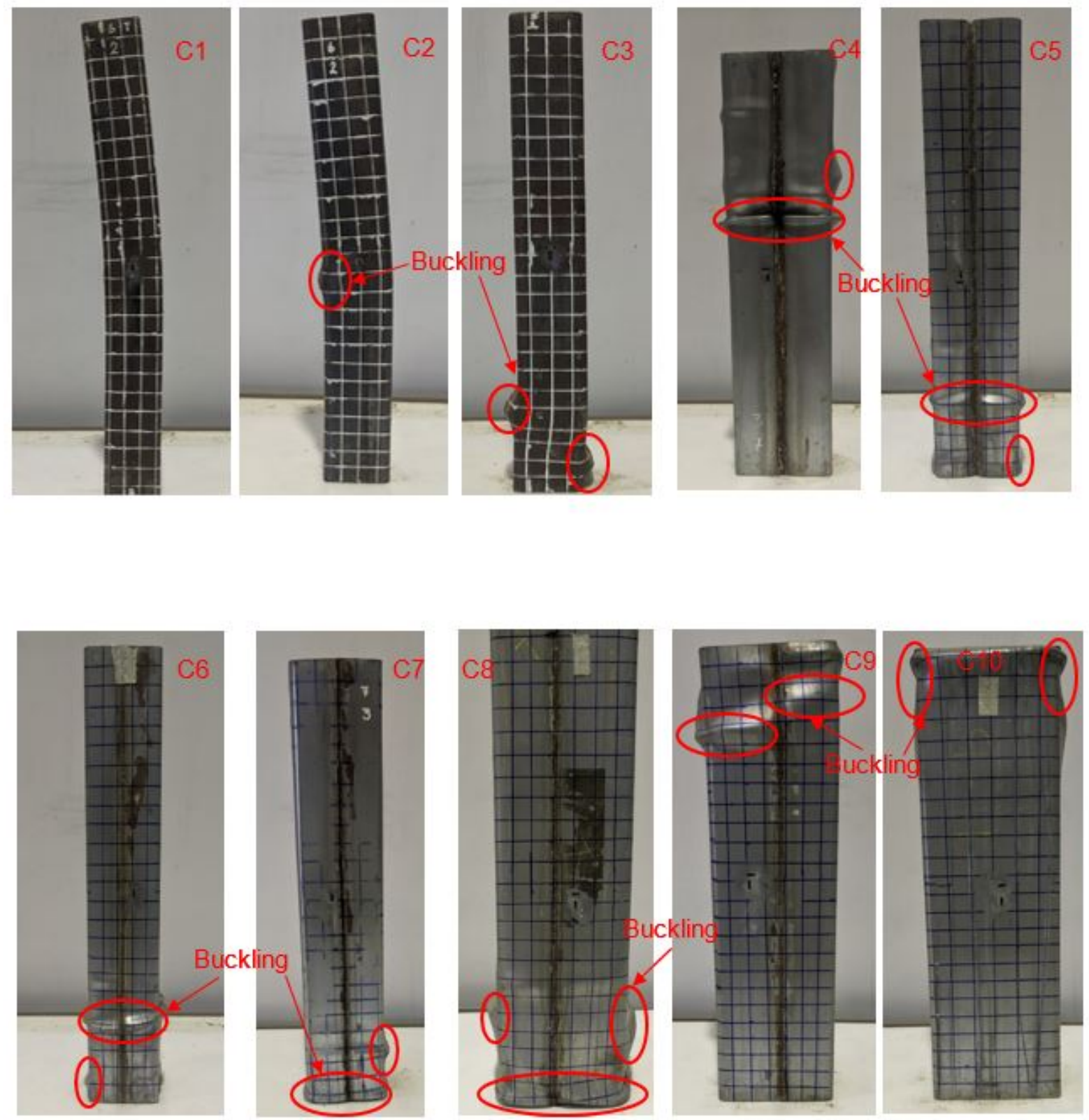

Figure 6. Buckling failure in CFST stub columns under concentric loading 

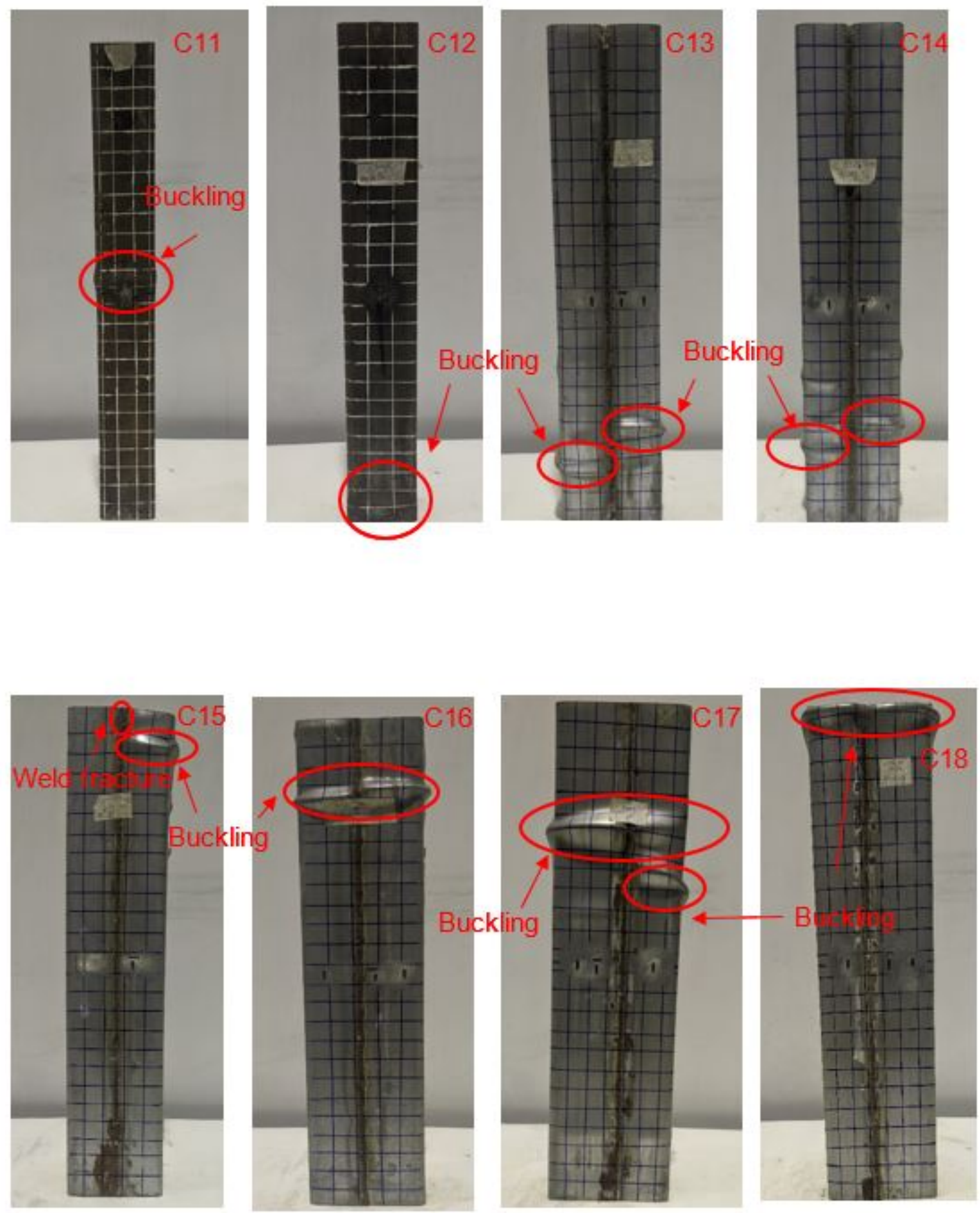

Figure 7. Buckling failure in CFST stub columns subjected to eccentric loading

\subsubsection{Eccentric Loading}

The failure mode of the CFST stub columns under eccentric loading is depicted in Figure 7. In C11, local buckling took place near to the column's mid-height.

The infilled-concrete was crushed close to the mid height of the CFST stub column and so on buckling failure of the steel tube, which was detected audibly during testing. For the unstiffened column C11, only half-wave outward buckling occurred along the transverse direction in the compression side of the C11 specimen. On the other hand, in C12, C15 and C18, buckling failure of the steel tube appeared close to the top and bottom ends for the eccentrically loaded CFST stub column specimens due to the end condition effects. In C13, C14, C16 and C17, local buckling appeared at in the steel tube at 120$125 \mathrm{~mm}$ from the top to bottom end. In the C15 specimen, 
weld fracture observed at the top of the column. In the CFST column, the weld fracture was caused by the insufficient weld size. The CFST stub column's strength was unaffected by the weld failure. The CFST stub columns measured ultimate load when loaded eccentrically to failure is given in Table 2 .

\subsection{Experimental Load-Displacement Relationships}

\subsubsection{Concentric Loading $(\mathrm{e}=0$ )}

The tested CFST stub column specimens were divided into 3 groups, as shown in Figure 8. In specimens C1, C2, and C3 without stiffeners, the compression load increased rapidly at the beginning prior to the maximum load was applied. Then, the load began to decrease, with vertical deformation increasing after achieving the ultimate load. The ultimate loads of C6 and C7, with values of $576 \mathrm{kN}$ and $542 \mathrm{kN}$, respectively, were significantly higher than for C4 and C5. The peak loads of the square CFST stub columns (C6 and C7) increased with an increment in the number of longitudinal stiffeners compared to the square CFST stub columns (C4 and C5), as illustrated in Figure 8(b). It was concluded that the peak load and the maximum vertical deformation of the CFST stub column with 4 longitudinal inner stiffeners were much higher than for the CFST stub column with 2 longitudinal inner stiffeners, which proved that the longitudinal inner stiffener was very useful in enhancing the mechanical performance of the square CFST stub column. Compression testing of the CFST stub columns (C8, C9 and C10) having b/t values of 44 and 99 produced higher peak load values of 937,880 and $994 \mathrm{kN}$, respectively, compared to the other slender specimens due to the greater steel and concrete areas.

\subsubsection{Eccentric Loading}

The axial load-deformation relationships of the test specimens are depicted in Figure 9. It may be determined from Figure 9 that prior to the peak load was developed, axial deformations increased with increasing loads. The longitudinal strain gauge mounted to the tube wall was used to determine how much the compression and tension flanges yielded. For C14, reliable axial deformations were not obtained from the LVDTs. For all specimens, the concrete infill was originally cracked slightly prior to the maximum axial compressive load, implying that concrete crushing was the primary cause of loss of ultimate load-carrying capacity. The ultimate bearing strength of the C16 column subjected to eccentric load with $25 \mathrm{~mm}$ eccentricity was $6.3 \%$ greater than that of the C14 column, while the ultimate bearing capacity of the C15 column under eccentric load with an eccentricity of $25 \mathrm{~mm}$ was $3.15 \%$ lower than that of the C13 column due to fracture welding. This result indicated that the stiffeners were successful in preventing local buckling in the slender CFST columns. 


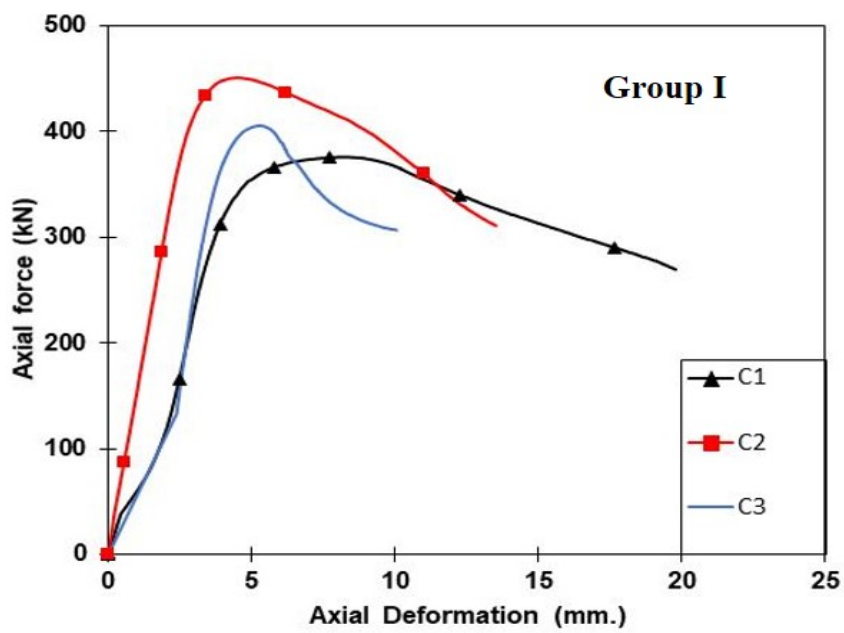

(a)

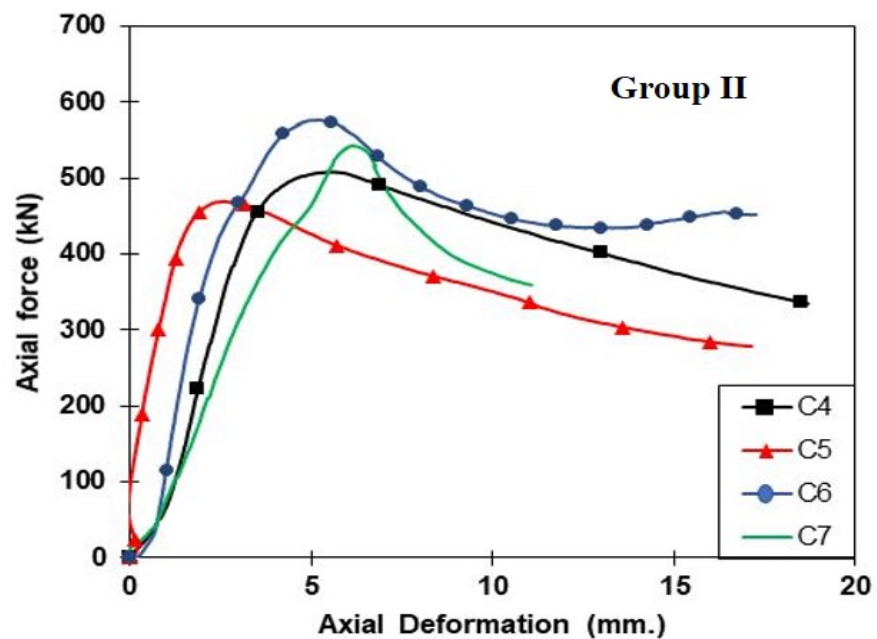

(b)

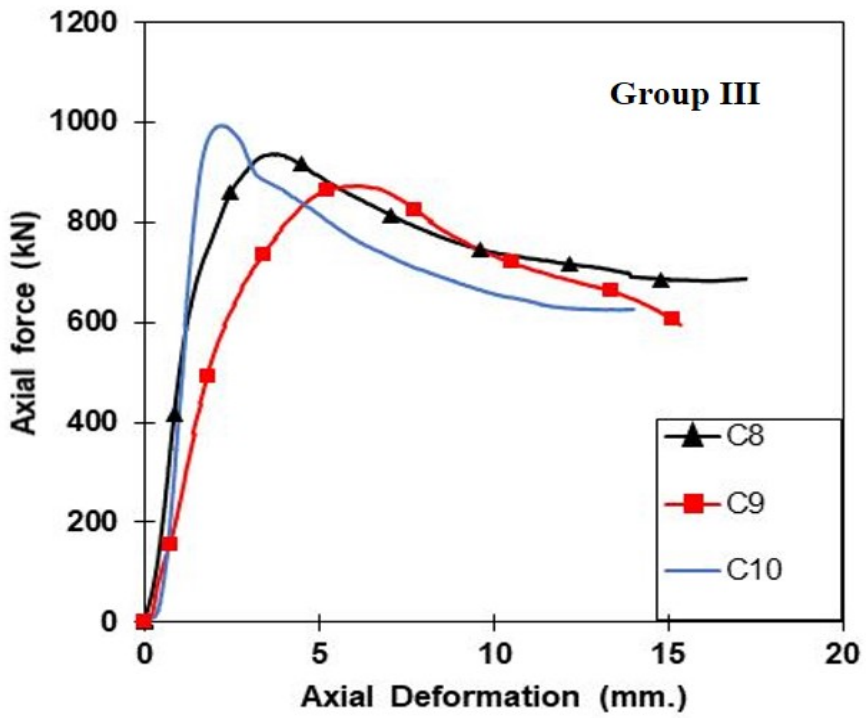

(c)

Figure 8. Relationships between axial load and axial deformation of all CFST columns 


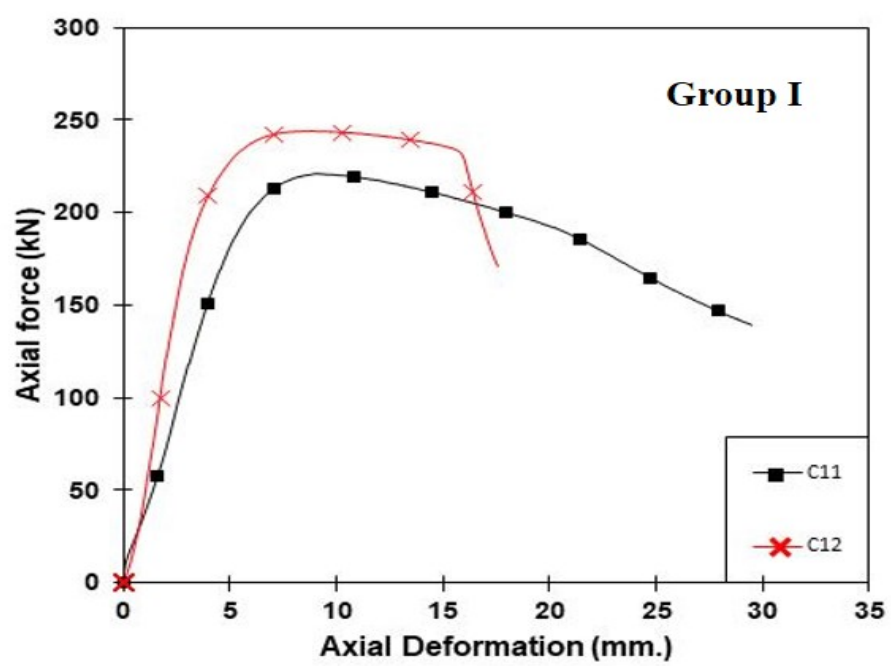

(a)

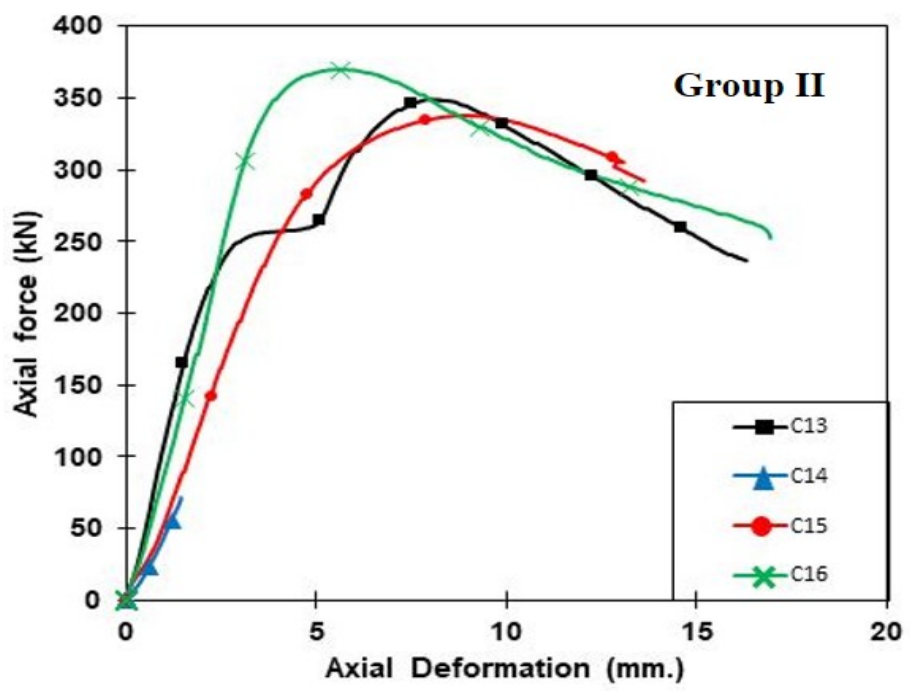

(b)

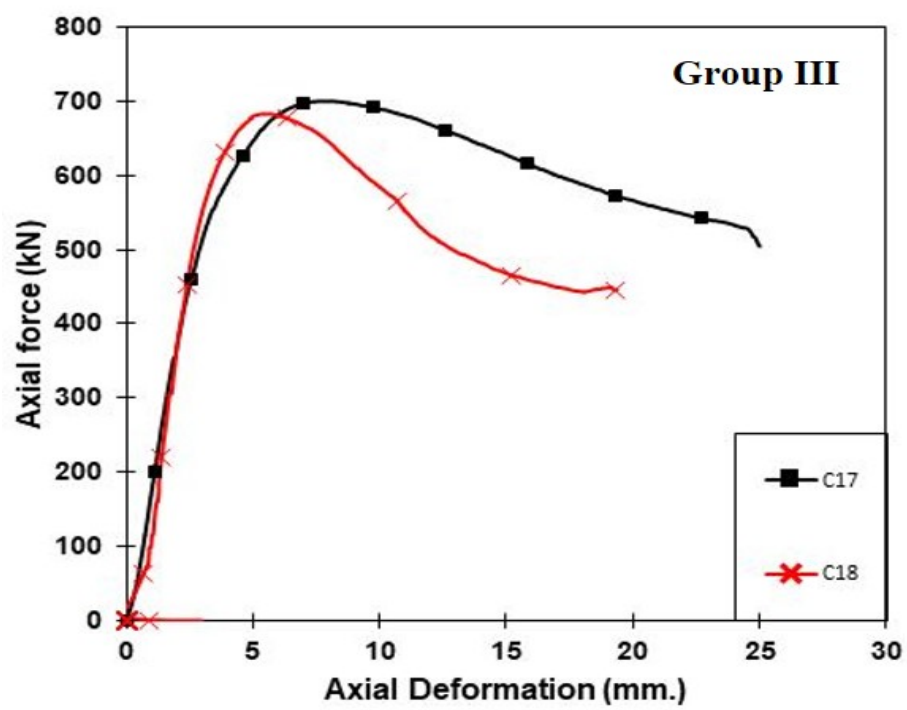

(c)

Figure 9. Relationships between eccentric axial load and axial deformation for all CFST columns 


\subsection{Comparison between Standard Code and Experimental Result}

\subsubsection{Existing Design Code}

The design for plastic cross-sectional resistance of the CFST column without longitudinal reinforcement may be calculated based on one of the two techniques provided on this section. The first technique is the general method, which ignores the increment in concrete's compressive strength owing to the confinement effect. The second technique is the simplified method which considers the reduction factor of the compressive strength capacity of a steel tube due to lateral stress, the influence of the imperfections and the confinement effect. The compressive resistance capacity of the CFST column can be calculated based on the Eurocode4 (2004) equation as:

$$
N_{p l, R d}=A_{a} f_{y d}+A_{c} f_{c d}
$$

where the cross sectional areas of the steel tube and concrete are $A_{a}$ and $A_{c}$, respectively, and the yield characteristics of a steel tube in compression and the characteristic compressive strength of concrete are $f_{y d}$ and $\mathrm{f}_{\mathrm{cd}}$, respectively.

The American National Standard ANSI/AISC 360-16 for a steel section is based on the steel tube slenderness limits to classify the composite section as compact if the width-to-thickness ratio $(\lambda) \leq \lambda \mathrm{p}\left(\lambda_{\mathrm{p}}=2.26\left(\mathrm{E}_{\mathrm{s}} / \mathrm{f}_{\mathrm{y}}\right)^{0.5}\right)$; if $\lambda_{\mathrm{p}}$ $<\lambda \leq \lambda_{\mathrm{r}}\left(\lambda_{\mathrm{r}}=3.0\left(\mathrm{E}_{\mathrm{s}} / \mathrm{f}_{\mathrm{y}}\right)^{0.5}\right)$, the CFST column is categorized as a noncompact section; and if the tube width-to-thickness ratio $(\lambda)$ exceeds $\lambda_{\mathrm{r}}\left(\lambda_{\mathrm{r}}=3.0\left(\mathrm{E}_{\mathrm{s}} / \mathrm{f}_{\mathrm{y}}\right)^{0.5}\right)$, the composite section is considered as a slender section, where $E_{s}$ represents Young's modulus. For a compact section, the nominal compressive strength can be calculated using equation (2), the nominal axial strength of the noncompact section can be calculated using equations (3) and (4) and the compressive strength of a CFST column with a slender section can be calculated using equations (5) and (6). The axial strength of a composite member is determined by the yield strength of the steel tube $\left(f_{y}\right)$, the compressive strength of the concrete $\left(\mathrm{f}_{\mathrm{c}}{ }^{\prime}\right)$, the width-to-thickness ratio $(\mathrm{b} / \mathrm{t})$, and the bonding strength of the concrete and steel tube, according to ANSI/AISC360-16. When the steel tube's strength reaches its yield stress, CFST columns with compact sections can improve the confinement of the concrete infill, increasing its axial strength to $0.85 \mathrm{fc}^{\prime}$.

For a compact section,

$$
P_{n o}=P_{p}=f_{y} A_{s}+0.85 f_{C}^{\prime} A_{C}
$$

For a noncompact section,

$$
\begin{gathered}
P_{\text {no }}=P_{p}-\frac{P_{p}-P_{y}}{\left(\lambda_{r}-\lambda_{p}\right)^{2}}\left(\lambda-\lambda_{p}\right)^{2} \\
P_{y}=f_{y} A_{s}+0.70 f_{c}^{\prime} A_{c}
\end{gathered}
$$

For a slender section,

$$
\begin{gathered}
P_{n o}=F_{C r} A_{S}+0.70 f_{C}^{\prime} A_{C} \\
F_{C r}=\frac{9 E_{S}}{\left(\frac{B}{t}\right)^{2}}
\end{gathered}
$$

where $P_{n o}$ is the cross-sectional strength without a length effect and $\mathrm{P}_{\mathrm{y}}$ is the yield strength of the composite compression member. The critical buckling stress $\left(\mathrm{F}_{\mathrm{cr}}\right)$ can be determined using equation (6) which is based on the width-to-thickness ratio.

\subsubsection{Comparison between Design Code and Experimental Results}

The effect of the longitudinal stiffeners of square CFST stub columns on the axial compression load capacity of square CFST stub columns was investigated using the ultimate load capacity of square CFST stub columns. Equations (1), (2), (3), (4), (5), and (6) show the formulas for predicting the ultimate strength of CFST stub columns. The ultimate strengths of the 10 CFST stub column samples attained from the axial compressive loading tests were compared with the ultimate load capacities computed according to equations (1), (2), (3), (4), (5) and (6), as shown in Table 3 , where $\mathrm{N}_{\text {ue }}$ is the CFST stub column s' ultimate load capacity as determined by axial compressive load tests. Table 3 indicates the average and STD of the observed strengths to the calculated strength ratios are 1.74 and 0.86 , respectively. Furthermore, Table 3 indicates that EC4 gives excellent estimates of the ultimate strength capacity. The mean $\mathrm{N}_{\mathrm{ue}} / \mathrm{N}_{\mathrm{EC} 4}$ ratio is 1.07 and the standard deviation is 0.09 . However, EC4 overestimated the strength for 3 columns. It could be inferred that EC4 would typically predict too much capacity for the CFST columns. The comparisons shown in Table 3 indicated that AISC was conservative for the design strength of CFST columns using high strength steel and normal strength steel because $\mathrm{N}_{\mathrm{ue}} / \mathrm{N}_{\mathrm{AISC}}$ is greater than one. Table 3 shows that $\mathrm{N}_{\mathrm{ue}} / \mathrm{N}_{\mathrm{AISC}}$ of column C10 was only 1.74. Because of this, AISC was used to determine the local buckling failure effect in the steel tube where the local buckling effect leads to unstable failure of the CFST column before the strength of the steel tube reached yield strength of steel. Therefore, the value of critical buckling strength was considerably underestimated. This resulted in substantial underestimation of the ultimate strength of these columns. It must be mentioned that the design equation in the slender section was developed by finding the relation between the critical buckling stress and the width-to-thickness ratio. The ultimate load of the rectangular CFST (C10) is displayed in Table 3. Here, it can be seen that for the 2 longitudinal rectangular sections of the CFST stub columns, the computed ultimate strengths based on AISC for the concrete-filled columns were very low compared to EC4. There was only 1 CFST 
stub column specimen with an $\mathrm{N}_{\mathrm{ue}} / \mathrm{N}_{\text {AISC }}$ ratio less than 1 . As shown in Table 3, the compact section in AISC360 overestimated the ultimate strength for many columns. There were 6 specimens with $\mathrm{N}_{\mathrm{ue}} / \mathrm{N}_{\mathrm{AISC} / \text { compact }}$ ratios less than one, with the minimum being 0.86 .

To compare the existing design code and the test result, the N-M interaction curve was computed and compared with the test results in Figure 10. $\mathrm{M}$ is the ultimate bending moment capacity of the CFST stub column attained from the eccentric compressive load tests (Table 2). The red point represents the ultimate axial load and associating bending moment which represents the bearing capacity of the CFST stub column. As illustrated in Figure 10, the AISC360 standard code is conservative in predicting the ultimate bearing capacities for square CFST stub columns with non-longitudinal stiffener, 2 longitudinal inner stiffeners and 4 longitudinal inner stiffeners in this research. The combined compression and bending resistance of specimen C15 was considerably lower than the AISC strength interaction curve because C15 with eccentric loading failed prematurely at the weld fracture of the CFST stub column under the applied load, as shown in Figure 7.

Table 3. Comparison of test results and expected ultimate strengths

\begin{tabular}{|c|c|c|c|c|c|c|c|c|}
\hline No. & $\mathbf{b} / \mathbf{t}$ & $\mathbf{N}_{\mathrm{ue}}(\mathbf{k N})$ & $\mathbf{N}_{\text {AISC }}(\mathbf{k N})$ & $\mathrm{N}_{\mathrm{EC} 4}(\mathrm{kN})$ & $\mathrm{N}_{\text {AISC/Compact }}(\mathrm{kN})$ & $\mathbf{N}_{\mathrm{ue}} / \mathbf{N}_{\mathrm{AISC}}$ & $\mathbf{N}_{\mathrm{ue}} / \mathbf{N}_{\mathrm{EC} 4}$ & $\mathbf{N}_{\text {ue }} / \mathbf{N}_{\text {AISC/compact }}$ \\
\hline $\mathrm{C} 1$ & 16 & 375 & 325 & 320 & 337 & 1.15 & 1.17 & 1.11 \\
\hline $\mathrm{C} 2$ & 21 & 450 & 447 & 430 & 458 & 1.01 & 1.04 & 0.98 \\
\hline $\mathrm{C} 3$ & 29 & 405 & 420 & 417 & 441 & 0.96 & 0.97 & 0.92 \\
\hline $\mathrm{C} 4$ & 66 & 507 & 471 & 516 & 573 & 1.08 & 0.98 & 0.88 \\
\hline C5 & 66 & 469 & 451 & 497 & 548 & 1.04 & 0.94 & 0.86 \\
\hline C6 & 32 & 576 & 563 & 516 & 573 & 1.02 & 1.11 & 1.01 \\
\hline $\mathrm{C} 7$ & 32 & 542 & 540 & 497 & 548 & 1.01 & 1.09 & 0.99 \\
\hline $\mathrm{C} 8$ & 44 & 937 & 921 & 821 & 930 & 1.02 & 1.14 & 1.01 \\
\hline C9 & 44 & 880 & 873 & 782 & 881 & 1.01 & 1.13 & 0.99 \\
\hline $\mathrm{C} 10$ & 99 & 994 & 570 & 818 & 926 & 1.74 & 1.21 & 1.07 \\
\hline \multicolumn{6}{|c|}{ Mean } & 1.10 & 1.07 & 0.98 \\
\hline \multicolumn{6}{|c|}{ Standard Deviation } & 0.22 & 0.09 & 0.07 \\
\hline
\end{tabular}

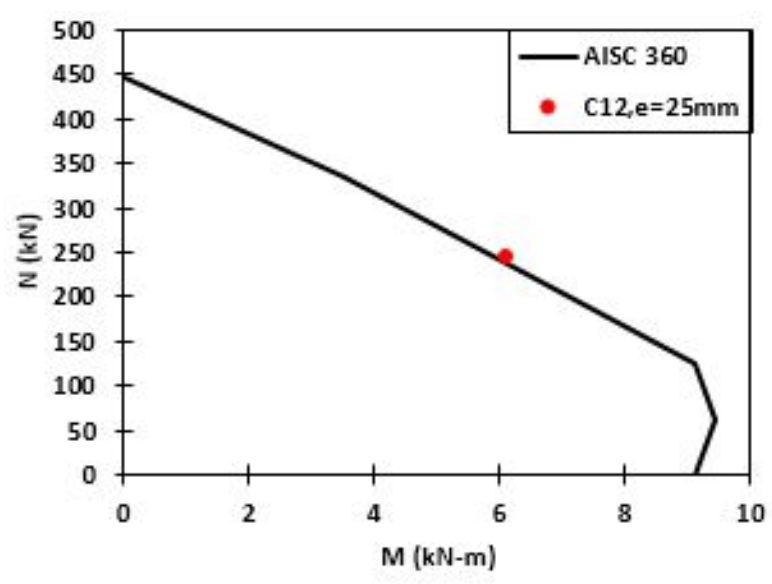

(a)

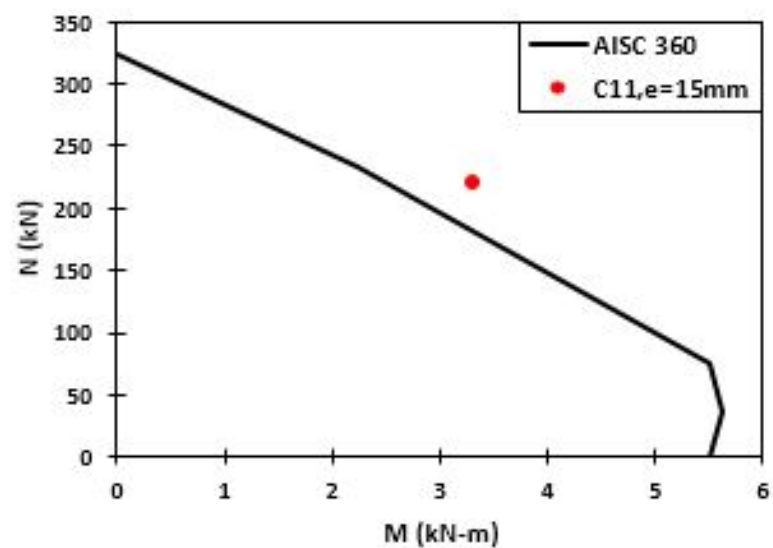

(b) 


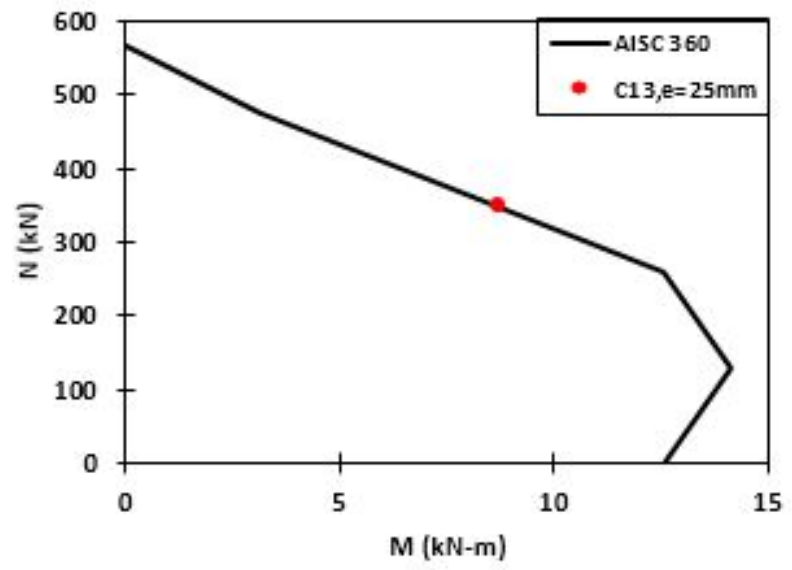

(c)

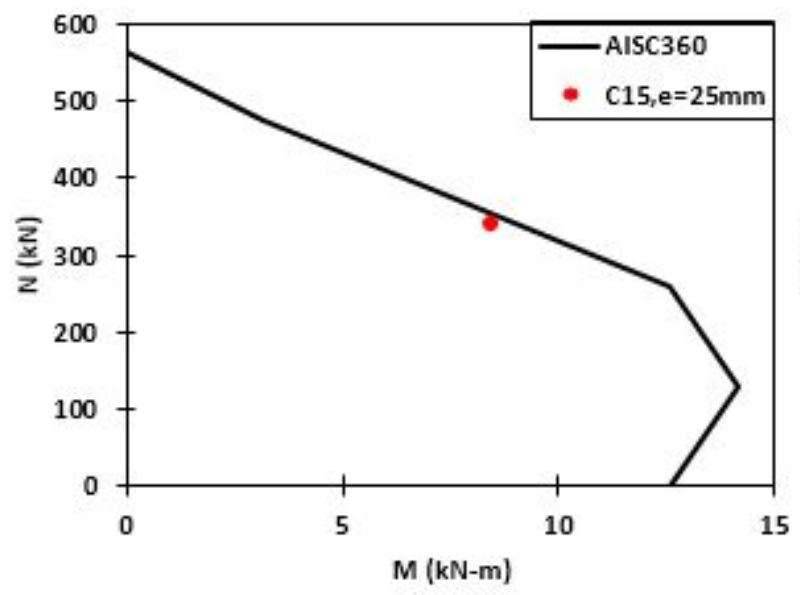

(e)

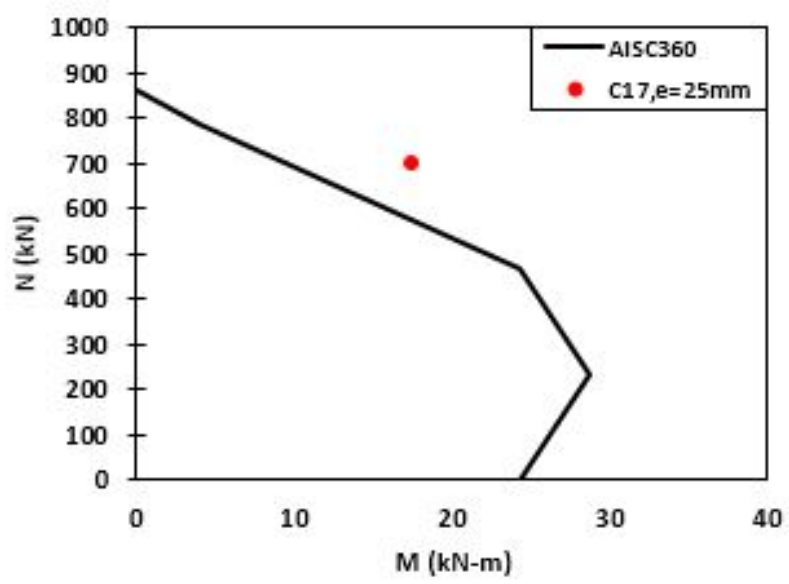

(g)

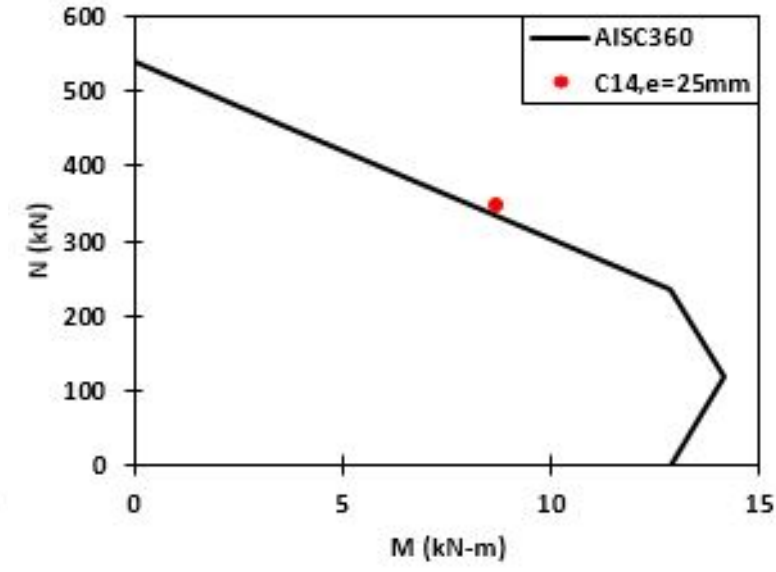

(d)

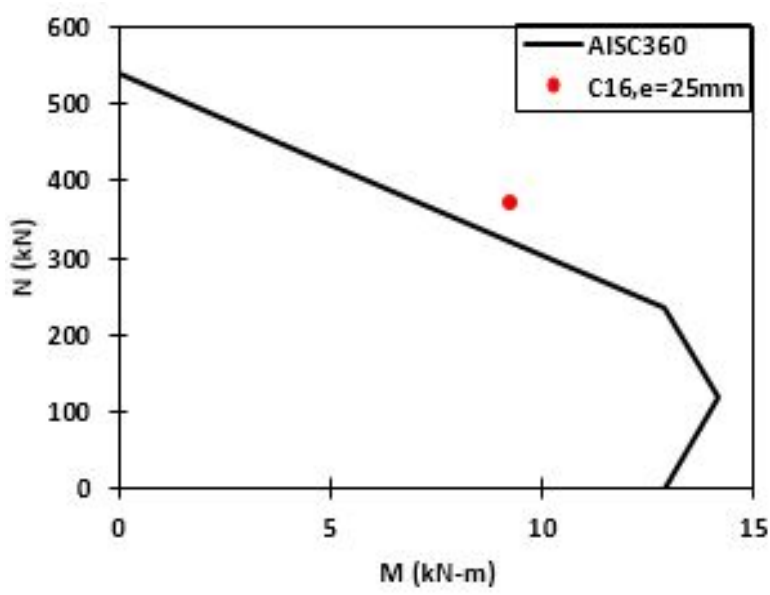

(f)

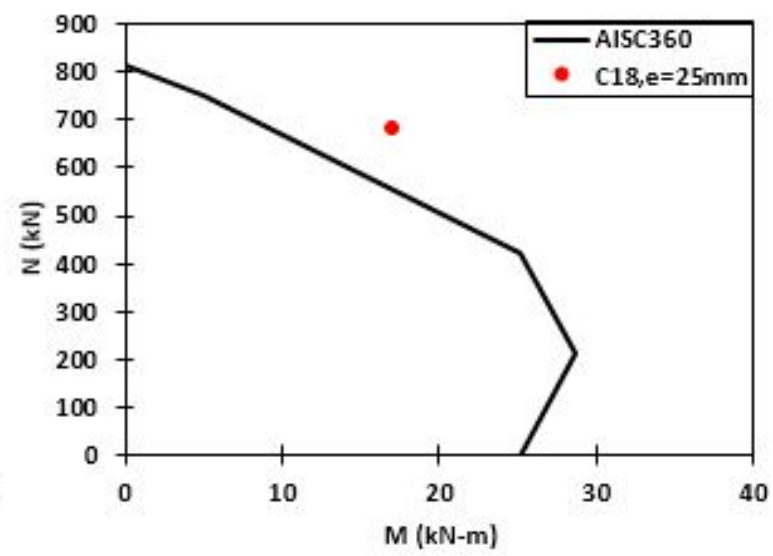

(h)

Figure 10. Interaction diagram of all CFST stub column specimens for a) C11, b) C12, c) C13, d) C14, e) C15, f) C16, g) C17, h) C18

\subsection{Analytical Relationship between Force and Slip of CFST Column with Stiffener}

For the square column specimens C6 and C7, local buckling of the steel tubes upon reaching the yield strength occurred much more slowly than for the square column specimens C4 and C5. To investigate the slip of stiffener on the CFST stub column, the free-body diagram of the square CFST column was predicted (Figure 11). The longitudinal stiffener can be considered as the horizontal load placing on the steel tube in the horizontal direction. The method of consistent deformation of the stiffener is given in equation (7), 


$$
\Delta S_{0}=\left(\frac{5 f_{l} B^{4}}{384 E I}\right)-\left(\frac{B^{3}}{48 E I}\right) F_{S n}
$$

where $f_{l}$ denotes the lateral confinement pressure, $B$ denotes the column width, $\Delta \mathrm{S}_{0}$ is the slip between the stiffener and the in-filled concrete,

If the lateral confinement pressure $\left(\mathrm{f}_{\mathrm{l}}\right)$ for a square section can be calculated using Susantha [9], E is the modulus of elasticity, $\mathrm{F}_{\mathrm{sn}}$ is the stiffener force, and $\mathrm{I}$ is the moment of inertia:

$$
f_{l}=\left(v_{e}-v_{S}\right) \frac{2 t}{(B-2 t)} f_{y}
$$

where $v_{e}$ is Poisson's ratio of the steel tube with in-filled concrete, $v_{s}$ is Poisson's ratio of the steel tube without in-filled concrete and $B, f_{y}$ and $t$ denote the width of the square section, the yield stress of the steel tube and the thickness of the square steel tube, respectively. Clotilda Petrus [10] carried out push out experiments on CFST with stiffeners. The bond strength at the interface between the steel tube and the in-filled concrete was 0.4 MPa. At the ultimate bond strength, slippage occurred at $5 \mathrm{~mm}$. The stiffener force was computed using equations (7) and (8), producing a value $90.53 \mathrm{kN}$. Therefore, the embedded length was $226 \mathrm{~mm}$. The experimental result shows that embedding stiffeners into the concrete increases the ultimate load of square CFST stub column. Compared to the $226 \mathrm{~mm}$ inner stiffener giving completely restrained in the concrete, the steel tube is subjected to tension but concrete is under compressive force when the steel tube could result in the high lateral confining pressure. However, length of stiffeners $\left(h_{s}\right)$ was carried out at 13.5 $\mathrm{mm}$ for CFST stub columns. It would be logical to expect longitudinal inner stiffeners still could improve the performance of square CFST stub column with low lateral confining pressure.

\section{Conclusions}

This study used square CFST and rectangle CFST columns in an experimental setting. In this research, 18 CFST stub column specimens were assembled for testing two types of steel tube, the number of longitudinal stiffeners and the width-to-thickness ratio to evaluate the structural capacities of the CFST stub columns. The conclusions reached were:

\subsection{Concentric Loading}

All CFST stub columns (from C4 to C10) with high-tensile cold-rolled steel loaded concentrically failed by outward steel tube local buckling and the crushing of the infilled-concrete. Local buckling occurred at the top, mid-height and bottom of the column. The CFST stub columns (C2 and C3) with cold-formed carbon steel, although classified as compact sections, early outward local buckling failure of the steel tube occurred before the ultimate capacity of the CFST columns. Regarding the compact section $\mathrm{C} 1$, global buckling when the maximum load was developed.

The ultimate strength capacity of 2 longitudinal stiffener steel tubes was lower than that of 4 longitudinal stiffener steel tubes. This was attributed to the fact that the buckling mode shape of the 4 longitudinal stiffener steel tubes could change from single curvature to double curvature. According to the findings of this research, the compressive strength of CFST columns attached with four stiffeners was greater than that of CFST columns attached with two stiffeners (both with and without a center hole), with a $12 \%$ higher compressive strength for the CFST columns attached with four stiffeners compared to CFST columns attached with two stiffeners. There was 13.5\% higher compressive strength with the center hole for a CFST column attached with 4 stiffeners compared to one with 2 stiffeners.

Ten tests were conducted to evaluate two design codes for predicting the ultimate strength of CFST columns. AISC360 was very conservative in its design specifications for CFST stub columns with normal strength steel and high strength steel. For rectangular CFST stub column with 2 stiffeners, it must be cited that the design equation in a slender section was developed by finding the relation between the critical buckling stress and the width-to-thickness ratio. Thus, based on the current results, additional testing is needed to assess the actual accuracy of the various codes for calculating the capacity of rectangular CFST stub columns. 


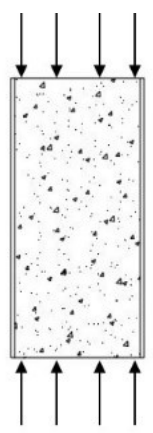

CFT COLUMN

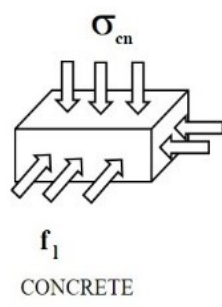

CONCRETE

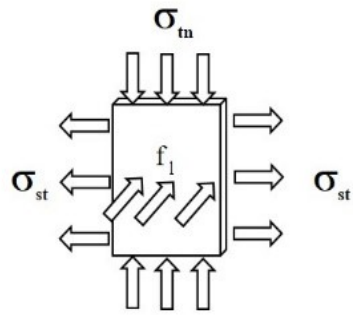

$\sigma_{\text {tn }}$
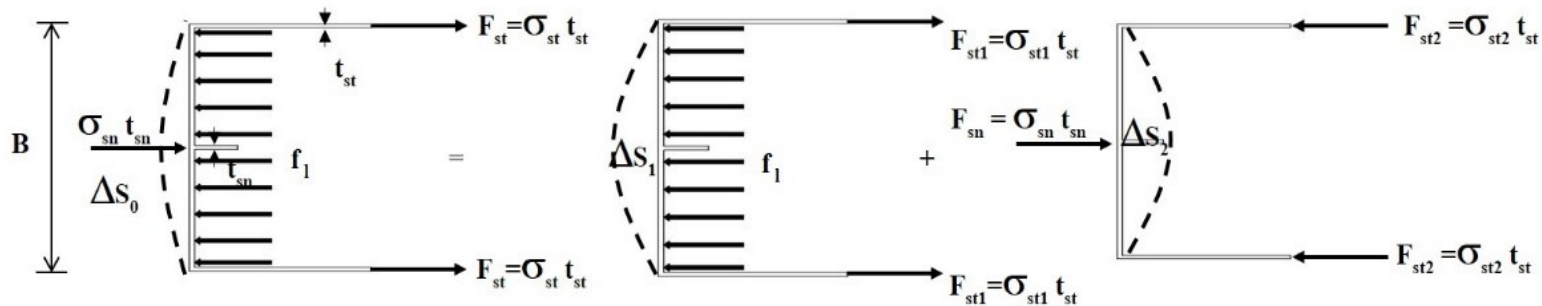

Figure 11. Force equilibrium between steel tube and in-filled concrete

Based on this study analysis, it requires at $226 \mathrm{~mm}$ embedded inner stiffeners to develop fully fixed in concrete allow higher confinement pressure within steel tube. Regarding observed results, the length of stiffeners $\left(h_{s}\right)$ of $13.5 \mathrm{~mm}$ for CFST stub columns improves the loading capacity of square CFST stub columns with increasing lateral confinement pressure.

\subsection{Eccentric Loading}

All square CFST stub columns loaded eccentrically failed by outward local buckling (C13-C18) and global buckling (C11-C12). In specimens C11 and C12 with a nonlongitudinal inner stiffener, despite the section was categorized as a compact section, early outward local buckling of the CFST columns took place prior to the maximum load. The ultimate strength capacity using 2 longitudinal stiffener steel tubes was lower than that for 4 longitudinal stiffener steel tubes.

AISC360 can be used to design square CFST stub columns with or without longitudinal inner stiffeners, two longitudinal inner stiffeners, or four longitudinal inner stiffeners. The strength interaction equations compared with the experimental results provided properly conservative forecasts for compact and slender square stub columns.

\section{REFERENCES}

[1] H.B. Ge, T. Usami. Structural of Concrete-Filled Thin-Walled Steel Box Column: Experimental, Journal of
Structural Engineering, ASCE, Vol 18, No.11, pp. 3036-3054, 1992.

[2] R.Q. Bridge, M.D. O’Shea. Behaviour of Thin-Walled Steel Box Sections with or without Internal Restraint, Journal of Constructional Steel Research, Vol.47, pp.73-91, 1998.

[3] L.H. Han. Tests on Stub Columns of Concrete-Filled RHS Sections. Journal of Constructional Steel Research, Vol58, pp.353-372, 2002.

[4] Z. Tao, L.H. Han, Z.B. Wang. Experimental Behaviour of Stiffened Concrete-Filled Thin-Walled Hollow Steel Structural (HSS) Stub Columns, Journal of Constructional Steel Research, Vol 61, pp. 962-983, 2005.

[5] Y. Yang, Y. Wang, F. Fu, Effect of Reinforcement Stiffeners on Square Concrete-Filled Steel Tubular Columns Subjected to Axial Compressive Load, Journal Thin Walled Structure, Vol82, pp.132-144, 2014.

[6] H.J. Lee, I.R. Choi, H.G. Park, Eccentric Compression Strength of Rectangular Concrete-Filled Tubular Columns Using High-Strength Steel Thin Plates, Journal of Structural Engineering, 2016, DOI:10.1061/(ASCE)ST.1943-541X.0 001724.

[7] Y. Du, Z. Chen,J.Y. Richard Liew, M.X. Xiong, Rectangular Concrete-Filled Steel Tubular Beam-Columns Using High-Strength Steel: Experiments and Design, Journal of Constructional Steel Research, Vol 131,pp. 1-18, 2017.

[8] F. Yuan, H. Huang, M. Chen, Effect of Stiffeners on The Eccentric Compression Behaviour of Square Concrete-Filled Steel Tubular Columns, Journal Thin Walled Structure, Vol 135, pp. 196-209, 2019.

[9] K.A.S. Susantha,H. Ge, T. Usami, Uniaxial Stress-Strain Relationship of Concrete Confined by Various Shaped Steel Tubes, Journal Engineering Structures, Vol 23, pp. 1331-1347, 2001. 
[10] C. Petrus, H. Abdul Hamid, A. Ibrahim, J.D. Nyuin, Bond Strength in Concrete Filled Built-Up Steel Tube Columns with Tab Stiffeners, Canadian Journal of Civil Engineering, Vol 38, pp. 627-637, 2011, DOI:10.1139/L11-030

[11] Z. Lai,A.H. Varma, Noncompact and Slender Circular CFT Members: Experimental Database, Analysis, and Design, Journal of Constructional Steel Research, Vol 106, pp. 220-233, 2015.

[12] Z.B. Wang, Z. Tao, Q. Yu, Axial Compressive Behaviour of Concrete-Filled Double-Tube Stub Columns with Stiffeners,
Journal Thin Walled Structure, Vol 120, pp. 91-104, 2017.

[13] A. Zhu, X. Zhang, H. Zhu, J. Zhu, Y. Lu, Experimental Study of Concrete Filled Cold-Formed Steel Tubular Stub Columns, Journal of Constructional Steel Research, Vol 134, pp.17-27, 2017.

[14] EN 1994 1-1 (Euro code 4): Design of Composite Steel and Concrete Structures Part1-1: Ultimate Limit States, 2010.

[15] AISC 360-16: Specification for Structural Steel Building, Chapter I: Design of Composite Members AISC, 2016. 